\title{
The Politics of Small Businesses Survival in a Competitive Market: Problems and Solutions
}

\section{EFEBEH Vincent Eseoghene ${ }^{a}$, IKENGA Francis Ayegbuna ${ }^{b}$, ORHERO Abraham Ejogb ${ }^{c}$}

a,b,c Political Science Department DELSU, Abraka.

Article History: Received: 11 January 2021; Accepted: 27 February 2021; Published online: 5 April 2021

\begin{abstract}
The political nature of man has made stakeholders of small businesses to be involved in one survival strategies or the order which have left the equitable distribution of infrastructure and operations of businesses owners a challenge in these regards. The study tried to identify the various problems as well as solutions to the problems militating against the small-scale business politically. The sample subject of the study is the 10 entrepreneurs and 40 employees of small- scale business. The questionnaire is a major instrument used. Mean and the standard deviation was used to analyse responses The results of the study showed that government have put up a lot of support programme to promote small-enterprise business in the local government area under study but policies, programme application, mismanagement/misappropriation of fund hinders the growth of the smallscale business. It was recommended that government should collaborate with the industrialists of the various small-scale businesses to find out their financial, manpower and infrastructural facilities needs and satisfy them.
\end{abstract}

Keywords: Politics, Small Business, Survival, Competitive Market, Nigeria.

\section{Introduction}

In Nigeria today, there is a campaign everywhere on the need for everyone to be empowered in a business skill to boost the establishment of more small-scale businesses. The need to boost the establishment of smallscale businesses becomes necessary because large-scale businesses which were first adopted in Nigeria did not achieve full industrial development, since it was capital-intensive. It is known that small-scale businesses perform an important role in the development of the nation's economy. Due to the realization that industrialization is a key factor to national development, most countries, for example, Nigeria intensifies ceaseless efforts aimed at quickening the growth of industries through direct public and private investments, thereby creating favourable industrial climate. Small-Scale Enterprises in Ika South Local Government Will notice an alteration in the development of businesses effectively when strategies are deployed as Bell, (2004) noticed business growth is a function of good product policy. He noted that this strategy has moved companies far above board in business operations across developing countries. This Bell's strategy has made a big blow in cloud computing which has given rise to discoveries that changed world businesses all over. As cited by Johnson (2010). He asserted that they are tools to competitively gain advantage and soar in the business world particularly in product and leadership indices far better than any other competitor (Heizer and Render, 2011). Right direction and positioning win the strategic alliance and import.

The further assertion by Cagan (2009), as corroborated with Bell (2004), successful adoption of a mix of product and strategies and business strategy. He averred that companies should invest in strategies that can be in line with objectives, win market opportunities and promote competitive advantage. By giving the right attention to small businesses, Bell has made the single market a transformational ground that meets the varying needs of people irrespective of what their needs are. Entrepreneurs in the Local government understudy will therefore continue to strive and aspire to industrially achieve a strong base that will better their business in a developing nation.

Consequently, the developing countries master resources available to them to quicken their pace of development. It is due to this reason, the government of some West African States have adopted the establishment of small-scale industries in their developing programme. Small-scale business creates employment for a large percentage of Nigerians, although, the establishment of small-scale businesses is affected by inadequate finance. The survival strategies of small-scale enterprises can only be achieved through the availability of finance, raw material and manpower.

Organisations use strategies to strengthen and hold their resources very optimally even when it scarce through the transformation, cost production and maximization of location Heizer and Render 2011). Stream decision was used in this context to define strategy, (Mintzberg, 1978). That is not to limit strategy to a 
conscious plan perse but rather acceptable unconscious activities that have become a completely acceptable way for business organisations to succeed in a political turbulent environment. Two approaches were discussed by authors, planned and emergent approaches. The planned approach trusts that policies grow from conscious plans and nations which are directed towards the achievement of some predetermined goals. While, the emergent approach believers that plans are realized from comatose achieved out of trials and intuitions (Mintzberg, 1998). This means that "strategy can emerge not only from patterns of actions but also from clarifications of expressive accrual events" (Down et al, 2003).

Many examples of deliberate or intended strategies can be found in almost every corporate organization which usually expressed in their mission statements.

Deliberating on possible surviving strategies of small-scale business in Ika South Local Government we can say that the way to avoid problems is to look at those had failed in the past and avoid what lead to their failure. Although most cases of failure can be traced to poor management, manpower, finance, sourcing for raw material, recordkeeping e.t.c. But it must be known that entering into a business is a questionable venture and on a has failed as a result of any of the above problems, it is difficult to start an up again. Creditors, friends, banks e.t.c. would be more reluctant to loan the business money. Nevertheless, the problems encountered when running a small- scale business does not stop people from wanting to set up their own business. All efficient control of human material, financial resources with good marketing research are the basis for a successful business. The way you control your human resources efficiently well, matters a lot, if you cannot control but you have the finance, then there is a big case, but if everything is in place but the product or goods are not to be sold, then at that, it is a problem. The seminar work is to find out about the surviving strategies solution of small-scale business in Ika South Local Government.

\section{The Problem}

Most governments especially, Delta State government has continued to emphasize on the establishment of Small-Scale business, to the pace increase of economic development to increase the standard of living and reduce the number of unemployment of people in Ika South Local Government Area of Delta State. Unfortunately, the march towards rapid industrialization has been quite difficult due to several constraints such as the politics of small-scale businesses, lack of business focus, inability to separate business from the family inadequate market analysis and lack of infrastructure such as electricity, water and good roads (Okpara J.O and Wynn, 2007), Mukailo, Hyanda and Sidikat (2011) Udechukwu (2003) attributed that poor performance to the effects of globalization and increased competition thus; small-scale businesses are struggling to survive among larger corporations. Given this, small-scale businesses need alternative approaches to stay in business. This study will present an alternative method of reviving small-scale businesses through their business strategies to boost the Nigerian economy in the long run.

\section{Purpose}

The major purpose of the study is to identify and assess the survival strategies solution of small-scale businesses politically in Ika South Local Government Area of Delta State.,

Specifically, the study will:

a. Identify the problems militating against the survival of small Scale business politically in Ika South Local Government Area.

b. Determine the survival strategies for small-scale business politically in Ika South Local Government Area of Delta.

\section{Research Questions}

The following questions have been developed for this study:

1. What are the problems militating against the survival of small-scale business politically in Ika South Local Government?

2. What is the Survival strategy for small-scale business politically in Ika South Local Government Area of Delta State? 


\section{Research Hypotheses}

The following Null hypothesis was tested at 0.05 level of significance.

$\mathrm{H}_{01}$ : There is no significant difference between the mean response of entrepreneurs and employees of the small-scale business on the problem militating against the survival of small-scale business in Ika South.

$\mathrm{H}_{\mathrm{O} 2}$ : There is no significant difference between the mean response of entrepreneurs and employees of the small-scale business on the survival strategies for small-scale business in Ika South Local Government Area of Delta State.

\section{Review of Related Literature}

\section{Conceptual Framework}

Osuala (1993) and Amaewhulu (1993), have confirmed that the small-scale business plays a vital role in the operation of the nation's economy through the owners and managers of the enterprise.

The third National Development Plan (1975-1980) defined small scale business as a manufacturing establishment employing less than 10 people or whose investment in machinery and equipment does not exceed N600,000.

The Nigerian Bank for Commerce and Industry (NBCI) (1989-90) pointed out that a small-scale enterprise would have a total investment capital not exceeding N750,000 excluding land. Government's Scheme defined small-scale enterprise as any manufacturing processing or service business with capital investment not exceeding N150,000.

The small-scale business may be defined as a business that is independently owned and managed. It is an establishment with capital investment not exceeding 10 million and employs between 50 and 200 persons.

\section{Importance of Small-Scale Business}

1. Small-scale business generates employment for a lot of Nigerians. A lot of unemployed people and youths have found employment in small- scale industries. A lot of small retail shops, cottages, restaurant, poultry farms and telecommunication/telephone shops have been established and managed profitably by Nigerians who would have been unemployed till date.

2. Small-scale business has upgraded the social status of Nigerian youths, by showcasing them as very successful entrepreneurs and operators of small-scale industries.

3. It has uplifted the dignity of labour. There is the spirit of "me too", I can do it attitude. People deriving joy in working for themselves and seeing their business grow.

4. They promote the development of indigenous manpower as well as increasing local participation in the manufacturing sector.

5. It helps to bring about new grade and services and supply the needs of large industries, who have relied on the small-scale operators for business success.

\section{Small-Scale Business Survival Approaches}

Survival practices in small-scale businesses are typically those strategies and operational process options chosen by a business owner or operator to ensure the superior performance and competitiveness of their business. At a business unit level, they include the selection of strategies that competitively position the business in their environment (Porter, 1985). Whilst at a functional level, they include manager's choice of marketing, operational and human resource strategies and business, Storey (1994) conclusion that six factors significantly impact upon the performance of the business: legal structure, business size, age, industry sector and market, location and ownership. Selecting strategies for success is one of the most important decisions for small businesses (Borch, Huse, and Senneseth, 1999).

Many researchers have studied successfully strategies for small businesses (Atkins and Lowe, 1994; Berginseer, 2000; Collins and Lazier, 1995; Giaoutzi et al, 1988; Harker and Kotey, 1999). For example, Harker (1999) studied the activities that constitute a strategy and found that they can be grouped into functional areas. Therefore, the overall business strategy can be thought of in terms of functional areas strategies (Gaibraith and Schendel, 1983; Suryasa, 2019). 
Key functional areas and associated activities in the small-scale business are:

1. Marketing: It includes selecting customer target groups and gathering information on them to determine acceptable products and quality levels. It also covers price setting and choice of appropriate promotion techniques and distribution channels. Marketing also involves decisions on customer service and support (Vorhies and Harker, 2000).

2. Finance: It covers decisions on capital structure, methods of raising capital, capital expenditure, profit distribution and retention and working capital levels. It also includes performance monitoring, that is, budget preparation and variance analysis (Pierson, Brown, Easton, and 1-toward, 1998).

3. Human resources: It deals with staff recruitment and selection, employee training, performance assessment and remuneration, compensation, reward and disciplinary systems, industrial relations and levels of employee participation in decision making (Schuler, Dowling, Smart and Huber, 1992).

4. Production: It covers a selection of location and supplier's inventory and productivity levels, production technology and capacities, plant size and levels of efficiency in production (Atkin and Love, 1994).

5. Archer and Taylor (1994) provide ten survival strategies for small scale business to consider in competing with mega-discount chains. These precepts are (Archer and Taylor, 1994):

1. Focus completely on satisfying the customers;

2. Study the success of others;

3. Gather and analyze management information regularly;

4. Sharpen marketing skills;

5. Increase the customer's perception of value;

6. Position the business uniquely;

7. Eliminate waste;

8. Find something to improve every day;

9. Embrace change with a positive attitude

10. Pull the trigger and start the battle.

\section{Theoretical Framework}

\section{Piaget Theory of Cognitive Development}

The study was anchored on the cognitive theory as developed by Piaget, who first did the study of cognitive development in 1936 (Lizardo, 2004; Piaget, 1964). Users of the theory seek to illustrate the development and nature of human intelligence (Piaget, 1964). The initial domain for the study was on children's development and the concept was later expanded to address business endeavours (Lizardo, 2004). The fundamental focus of my study was political environments and survival strategies of small businesses in Delta State Nigeria. Nigerian small business owners successfully use to address challenges and risks. The conversational model provided a lens for understanding the findings. I used themes based on entrepreneurial thinking and behaviour. The theory was related to the study as it provided a potential means for understanding the development and deployment of successful strategies for sustaining political risks and challenges of small businesses in Delta State, Nigeria.

\section{Methodology}

The design of the study is the survey type. The study was carried out in Ika South Local Government Area of Delta State. The sample subject of the study is 10 proprietors and 40 employees of small-scale enterprise in Ika South Local Government Area. The instrument for the study is a 20 items questionnaire. The response set for research question one and two is based on the 4 points Likert rating scale. The reliability of the instrument was determined in a preliminary survey of the instrument on a sample size to establish the reliability of the instrument. The instrument was personally administered to the respondents. All the instruments administered were returned. The data collected whose mean are 2.50 and above are accepted, while the mean below 2.50 was rejected. The mean was used for analyzing the data collected while t-test statistics was used for testing the hypotheses at 0.05 level of significance.

\section{Data Analysis}

The analysis of the data was carried out using the techniques of the sample mean. Several 50 completed questionnaires were administered to entrepreneurs and employees. 
The research questions were analyzed using mean and standard deviation while the hypothesis was tested using t-test. A cut off point is 2.50 , any item mean of 2.50 and above is considered accepted while any item means less than or below 2.49 was not accepted.

Respondents mean and standard deviation rating of the factors militating against the survival strategies of small-scale business in Ika South Local Government. For decision making, a mean of 2.50 will be used as a cutoff point.

Table 1.

\begin{tabular}{|c|c|c|c|c|c|c|c|c|c|c|c|c|c|c|}
\hline \multirow{2}{*}{$\begin{array}{l}\mathbf{S} / \\
\mathbf{N}\end{array}$} & \multirow{2}{*}{$\begin{array}{l}\text { Factors militating against } \\
\text { the survival strategies of } \\
\text { small-scale business in Ika } \\
\text { South }\end{array}$} & \multicolumn{6}{|c|}{$\begin{array}{l}\text { Proprietors of Small-Scale } \\
\text { Business (10) }\end{array}$} & \multicolumn{6}{|c|}{$\begin{array}{l}\text { Employees of Small-Scale } \\
\text { Business (40) }\end{array}$} & \multirow{2}{*}{$\begin{array}{l}\text { Decisio } \\
\text { n }\end{array}$} \\
\hline & & $\begin{array}{l}\mathrm{S} \\
\mathrm{A}\end{array}$ & A & $\mathrm{D}$ & $\begin{array}{l}S \\
D\end{array}$ & $X$ & SD & $\begin{array}{l}\mathrm{S} \\
\mathrm{A}\end{array}$ & A & $\mathrm{D}$ & SD & $X$ & SD & \\
\hline 1 & $\begin{array}{l}\text { Strong competition from large } \\
\text { enterprises militates against } \\
\text { the survival scale business }\end{array}$ & 2 & 5 & 1 & 2 & $\begin{array}{l}2 . \\
7\end{array}$ & $\begin{array}{l}1.0 \\
5\end{array}$ & 16 & 16 & 4 & 4 & $\begin{array}{l}3 . \\
1\end{array}$ & $\begin{array}{l}0.9 \\
6\end{array}$ & $\begin{array}{l}\text { Accepte } \\
\text { d }\end{array}$ \\
\hline 2 & $\begin{array}{l}\text { Lack of } \\
\text { communication/transportation } \\
\text { facilities militate against the } \\
\text { survival of the small-scale } \\
\text { business }\end{array}$ & 3 & 5 & 1 & 1 & 3 & $\begin{array}{l}0.9 \\
4\end{array}$ & 16 & 18 & 4 & 2 & $\begin{array}{l}3 . \\
2\end{array}$ & $\begin{array}{l}0.8 \\
3\end{array}$ & $\begin{array}{l}\text { Accepte } \\
\text { d }\end{array}$ \\
\hline 3. & $\begin{array}{l}\text { Unavailability of a ready } \\
\text { market militate against the } \\
\text { survival of the small-scale } \\
\text { business }\end{array}$ & 3 & 4 & 1 & 2 & $\begin{array}{l}2 . \\
8\end{array}$ & $\begin{array}{l}1.1 \\
3\end{array}$ & 14 & 10 & 12 & 4 & $\begin{array}{l}2 . \\
85\end{array}$ & $\begin{array}{l}1.0 \\
3\end{array}$ & $\begin{array}{l}\text { Accepte } \\
\text { d }\end{array}$ \\
\hline 4. & $\begin{array}{l}\text { Instability in government } \\
\text { policies is a major factor that } \\
\text { militates against the survival } \\
\text { of the small-scale business }\end{array}$ & 3 & 1 & 5 & 1 & $\begin{array}{l}2 . \\
6\end{array}$ & $\begin{array}{l}1.0 \\
7\end{array}$ & 18 & 14 & 2 & 6 & $\begin{array}{l}3 . \\
1\end{array}$ & $\begin{array}{l}1.0 \\
7\end{array}$ & $\begin{array}{l}\text { Accepte } \\
\text { d }\end{array}$ \\
\hline 5 & $\begin{array}{l}\text { Inadequate knowledge of } \\
\text { business management } \\
\text { techniques is a major factor } \\
\text { that hinders the survival of the } \\
\text { small-scale business }\end{array}$ & 3 & 5 & 1 & 1 & 3 & $\begin{array}{l}0.9 \\
4\end{array}$ & 18 & 18 & 2 & 2 & $\begin{array}{l}3 . \\
3\end{array}$ & $\begin{array}{l}0.8 \\
0\end{array}$ & $\begin{array}{l}\text { Accepte } \\
\text { d }\end{array}$ \\
\hline 6 & $\begin{array}{l}\text { Insufficient capital hinders the } \\
\text { growth of the small-scale } \\
\text { business }\end{array}$ & 6 & 3 & 1 & - & $\begin{array}{l}3 . \\
5\end{array}$ & $\begin{array}{l}1.7 \\
0\end{array}$ & 22 & 10 & 6 & 2 & $\begin{array}{l}3 . \\
3\end{array}$ & $\begin{array}{l}0.9 \\
2\end{array}$ & $\begin{array}{l}\text { Accepte } \\
\text { d }\end{array}$ \\
\hline 7 & $\begin{array}{l}\text { Lack of proper planning leads } \\
\text { to liquidation of small-scale } \\
\text { business }\end{array}$ & 5 & 3 & 1 & 1 & $\begin{array}{l}3 . \\
2\end{array}$ & $\begin{array}{l}1.0 \\
3\end{array}$ & 26 & 8 & 4 & 2 & $\begin{array}{l}3 . \\
45\end{array}$ & $\begin{array}{l}0.8 \\
8\end{array}$ & $\begin{array}{l}\text { Accepte } \\
\text { d }\end{array}$ \\
\hline 8 & $\begin{array}{l}\text { Wrong utilization of business } \\
\text { resources retards the growth of } \\
\text { the small-scale business }\end{array}$ & 4 & 3 & 2 & 1 & 3 & $\begin{array}{l}1.0 \\
5\end{array}$ & 20 & 10 & 8 & 2 & $\begin{array}{l}3 . \\
2\end{array}$ & $\begin{array}{l}0.9 \\
5\end{array}$ & $\begin{array}{l}\text { Accepte } \\
\text { d }\end{array}$ \\
\hline 9 & $\begin{array}{l}\text { Lack of training personnel } \\
\text { hinders the growth of the } \\
\text { business }\end{array}$ & 3 & 4 & 1 & 2 & $\begin{array}{l}2 . \\
8\end{array}$ & $\begin{array}{l}1.1 \\
3\end{array}$ & 10 & 14 & 4 & 12 & $\begin{array}{l}2 . \\
55\end{array}$ & $\begin{array}{l}1.1 \\
9\end{array}$ & $\begin{array}{l}\text { Accepte } \\
\text { d }\end{array}$ \\
\hline 10 & $\begin{array}{l}\text { Restricted access to } \\
\text { institutional credit facilities } \\
\text { hinders the growth of the } \\
\text { small-scale business }\end{array}$ & 2 & 4 & 2 & 2 & $\begin{array}{l}2 . \\
6\end{array}$ & $\begin{array}{l}1.0 \\
7\end{array}$ & 8 & 16 & 6 & 10 & $\begin{array}{l}2 . \\
55\end{array}$ & $\begin{array}{l}1.0 \\
9\end{array}$ & $\begin{array}{l}\text { Accepte } \\
\text { d }\end{array}$ \\
\hline & Grand Mean/Standard & & & & & 2. & 1.0 & & & & & 3. & 0.9 & \\
\hline & Deviation & & & & & 92 & 1 & & & & & 06 & 7 & \\
\hline
\end{tabular}

From the result in table I above indicated that entrepreneurs and employees of small-scale business agreed that problems are militating against the survival of small-scale business with their grand mean response of 2.92 and 3.06, the standard deviation of 1.01 and 0.97 respectively, indicates homogeneity with each of the groups. 


\section{Hypothesis One}

There is no significant difference between the mean response of proprietors and employees of the small-scale business on the political problem militating against the survival of small-scale business in Ika South.

Table 2. T-test of difference between the mean response of proprietors and employees on the problem militating against the survival of small-scale business in Ika-South.

\begin{tabular}{|c|c|c|c|c|c|c|c|}
\hline & $X$ & SD & $\mathrm{N}$ & df & $\mathrm{t}$-cal & t-crit & Decision \\
\hline Proprietors & 2.92 & 1.01 & 10 & 48 & 0.4 & 2011 & Accepted \\
\hline Employees & 3.06 & 0.97 & 40 & 48 & 0.4 & 2.011 & \\
\hline
\end{tabular}

Table 2 shows the t-calculated of 0.4 and at-critical table value of 2.01 at 0.05 level of significance. Since the $\mathrm{t}$-critical is higher than the $\mathrm{t}$-calculated value the null hypothesis of no significant difference between the mean response of proprietors and employees is accepted.

\section{Research Question 2}

What are the survival strategies for small-scale business I South Local Government?

Table 3. Respondents mean and standard deviation rating of the survival strategies of small-scale business in Ika South Local Government

\begin{tabular}{|c|c|c|c|c|c|c|c|c|c|c|c|c|c|c|}
\hline \multirow{2}{*}{$\begin{array}{l}\mathbf{S} / \\
\mathbf{N}\end{array}$} & \multirow{2}{*}{$\begin{array}{l}\text { Factors militating against the } \\
\text { survival strategies of small-scale } \\
\text { business in Ika South }\end{array}$} & \multicolumn{6}{|c|}{$\begin{array}{l}\text { Proprietors of Small-Scale } \\
\text { Business (10) }\end{array}$} & \multicolumn{6}{|c|}{$\begin{array}{l}\text { Employees of Small-Scale } \\
\text { Business (40) }\end{array}$} & \multirow[t]{2}{*}{ Decision } \\
\hline & & SA & A & D & SD & X & SD & SA & A & D & SD & $X$ & SD & \\
\hline 11 & $\begin{array}{l}\text { Effective planning, budgeting and } \\
\text { forecasting will enhance the } \\
\text { survival of the small-scale } \\
\text { business }\end{array}$ & 4 & 4 & 1 & 1 & 3.1 & 0.99 & 12 & 20 & 6 & 2 & $\begin{array}{l}3.0 \\
5\end{array}$ & $\begin{array}{l}0.8 \\
2\end{array}$ & $\begin{array}{l}\text { Accepte } \\
\mathrm{d}\end{array}$ \\
\hline 12 & $\begin{array}{l}\text { Knowledge of accounting and } \\
\text { business management techniques } \\
\text { will improve the performance of } \\
\text { the small-scale business }\end{array}$ & 4 & 3 & 2 & 1 & 3 & 1.05 & 20 & 12 & 6 & 2 & $\begin{array}{l}3.2 \\
5\end{array}$ & $\begin{array}{l}0.9 \\
1\end{array}$ & $\begin{array}{l}\text { Accepte } \\
\text { d }\end{array}$ \\
\hline 13. & $\begin{array}{l}\text { Appropriate stock record keeping } \\
\text { inventory control will facilitate } \\
\text { the growth and survival of the } \\
\text { small-scale business }\end{array}$ & 2 & 4 & 1 & 3 & 2.5 & 1.17 & 12 & 10 & 8 & 10 & 2.6 & $\begin{array}{l}1.1 \\
8\end{array}$ & $\begin{array}{l}\text { Accepte } \\
\mathrm{d}\end{array}$ \\
\hline 14. & $\begin{array}{l}\text { Knowledge of seasonal } \\
\text { fluctuations of goods will } \\
\text { improve the performance of the } \\
\text { small-scale business }\end{array}$ & 4 & 2 & 3 & 1 & 2.9 & 1.10 & 18 & 12 & 8 & 2 & $\begin{array}{l}3.1 \\
5\end{array}$ & $\begin{array}{l}0.9 \\
3\end{array}$ & $\begin{array}{l}\text { Accepte } \\
\text { d }\end{array}$ \\
\hline 15 & $\begin{array}{l}\text { Proper use of advertising media } \\
\text { will enhance the survival of } \\
\text { small-scale }\end{array}$ & 3 & 4 & 1 & 2 & 2.8 & 1.13 & 14 & 18 & 4 & 4 & $\begin{array}{l}3.0 \\
5\end{array}$ & $\begin{array}{l}0.9 \\
4\end{array}$ & $\begin{array}{l}\text { Accepte } \\
\text { d }\end{array}$ \\
\hline 16 & $\begin{array}{l}\text { Low prices and incentives will } \\
\text { enhance the survival of the small- } \\
\text { scale business }\end{array}$ & 2 & 4 & 2 & 2 & 2.6 & 1.07 & 16 & 12 & 8 & 4 & 3 & $\begin{array}{l}1.0 \\
2\end{array}$ & $\begin{array}{l}\text { Accepte } \\
\text { d }\end{array}$ \\
\hline 7 & $\begin{array}{l}\text { Elimination of waste will } \\
\text { facilitate the growth of the small- } \\
\text { scale business }\end{array}$ & 3 & 5 & 1 & 1 & 3 & 0.94 & 18 & 14 & 2 & 6 & 3.1 & $\begin{array}{l}1.0 \\
7\end{array}$ & $\begin{array}{l}\text { Accepte } \\
\text { d }\end{array}$ \\
\hline 8 & $\begin{array}{l}\text { Provision of adequate } \\
\text { communication and transportation } \\
\text { facilities will improve the } \\
\text { performance of the small-scale } \\
\text { business }\end{array}$ & 3 & 4 & 1 & 2 & 2.8 & 1.13 & 14 & 18 & 4 & 4 & $\begin{array}{l}3.0 \\
5\end{array}$ & $\begin{array}{l}0.9 \\
4\end{array}$ & $\begin{array}{l}\text { Accepte } \\
\mathrm{d}\end{array}$ \\
\hline 9 & $\begin{array}{l}\text { Appropriate leadership } \\
\text { development will enhance the } \\
\text { survival of the small-scale } \\
\text { business }\end{array}$ & 7 & 2 & 1 & - & 3.5 & 0.97 & 20 & 14 & 4 & 2 & 3.3 & $\begin{array}{l}0.8 \\
6\end{array}$ & $\begin{array}{l}\text { Accepte } \\
\mathrm{d}\end{array}$ \\
\hline 10 & $\begin{array}{l}\text { Effective utilization of business } \\
\text { resources will facilitate the } \\
\text { growth and survival of the small- } \\
\text { scale business }\end{array}$ & 5 & 3 & 1 & 1 & 3.2 & 1.03 & 18 & 14 & 2 & 6 & 3.1 & $\begin{array}{l}1.0 \\
7\end{array}$ & $\begin{array}{l}\text { Accepte } \\
\text { d }\end{array}$ \\
\hline & Grand Mean/Standard Deviation & & & & & $\begin{array}{l}2.9 \\
4\end{array}$ & 1.05 & & & & & $\begin{array}{l}3.0 \\
6\end{array}$ & $\begin{array}{l}0.9 \\
7\end{array}$ & \\
\hline
\end{tabular}


Table 3 above indicates that survival of the small-scale business is through effective planning/budgeting, forecasting, knowledge of accounting and business management techniques, appropriate stock record-keeping, proper use of advertising media, low price and incentives. Elimination of waste, provision of adequate communication and transportation facilities, appropriate leadership development and effective utilization of business resources. The grand mean responses for the two groups of respondents are above the decision mean of 2.50. The standard deviation of 1.05 and 0.97 shows homogeneity of response agreement between the groups.

\section{Hypothesis Two}

There is no significant difference between the mean responses of sole proprietors and employees of the smallscale business on the survival strategies of small-scale business in Ika South Local Government Area of Delta State.

Table 4. T-test of difference between the mean responses of proprietors and employees on the survival strategies of small-scale business

\begin{tabular}{llllllll}
\hline & $\mathrm{X}$ & $\mathrm{SD}$ & $\mathrm{N}$ & $\mathrm{df}$ & $\mathrm{t}$-cal & t-crit & Decision \\
\hline Proprietors & 2.94 & 1.05 & 10 & \multirow{2}{*}{48} & \multirow{2}{*}{0.33} & \multirow{2}{*}{2.011} & \multirow{2}{*}{ Accepted } \\
Employees & 3.06 & 0.97 & 40 & & & \\
\hline
\end{tabular}

The data in table 4 indicate at-calculated of 0.33 and at-critical table value of 2.01 at 0.05 level of significance. Since the t-critical value is higher than the t-calculated value the null hypothesis of no significant difference between the mean responses of proprietors and employees is accepted.

\section{Discussion of Findings}

The findings of research question one on the factors that are militating against the survival strategies of smallscale business in Ika South. Various factors such as strong competition from large enterprises, lack of communication/transportation facilities, unavailability of a ready market, instability in Government policies, inadequate knowledge of business management techniques, insufficient capital, lack of proper planning, wrong utilization of business resources, lack of trained personnel and restricted access to institutional credit facilities. Management experience does not come easily. Small-scale business owners are mainly concerned with the present and fail to plan and for an emergency. Larger companies search constantly for management talent to meet future needs; they choose competent individuals and then carefully train them for the new or vacant position. This finding is supported by the findings of Lucey and Brass (2005). The Findings also supports Piaget's cognitive theory of development that needs experience in political and business factors in addressing business concerns.

The findings of the study also, however, indicates that survival strategies of small-scale business such as effective planning, budgeting, and forecasting accounting knowledge and business management techniques, appropriate stock recordkeeping, inventory control of seasonal fluctuation of goods; proper use of advertising media, low price and incentives, elimination of waste, provision of adequate communication and transportation facilities, appropriate leadership development and effective utilization of business resources will facilitate the growth and survival of the small-scale business. This is in agreement with some of the findings of Garba (2005), Azuka (2000) and Ogunna (2009). The study, however, revealed that of the major characteristic of the entrepreneur is the spirit of innovation. Innovation is to introduce something new or add value to something that already exists, Broom (2001). The finding is in agreement with the findings of (Adekunle, 2006).

\section{Conclusion}

Based on the findings of this study the following conclusion has been reached.

1. There are a lot of factors that militate against the survival of small- scale business in Ika South.

2. There is a need for further improvement on the survival strategies for small-scale business. Most objectives of small-scale business have not been realized.

\section{Recommendations}

The following recommendations have been made based on the findings of this study: 
a. Government should collaborate with the industrialist of the various small-scale enterprises to find out their financial, manpower, equipment and facilities needs and satisfy them.

b. The staff and management of a small-scale business should be put through periodic training to upgrade their competencies.

c. Policies and programmes of government should be devoid of political manipulations while the required backbone infrastructural provision should be a key aspect of government responsibility.

\section{References}

1. M.O. Agwu, and C.I. Emeti, "Issues, challenges and prospects of small and medium scale enterprises (SMEs) in Port-Harcourt City, Nigeria", European Journal of Sustainable Development, vol. 3, no. 1, pp. 101-114, 2014. https://doi.org/10.14207/ejsd.2014.v3n1p101

2. J.S. Archer, and D. Taylor, "Up against the Wal-marts (I-low your business can survive in the shadow of retail giant", American Management Association, 1994.

3. M. Atkins, and J. Lowe, "3 Stakeholder and the strategy formation process in small and medium enterprises", International Small Business, vol. 12, no. 3, pp. 12-24, 1994.

4. Akinsolo, A, "Successful Strategies for the Survival of Business Owners in Nigeria”, Doctoral Thesis, Walden University Studies Collection, 2018.

5. W.I. Azuka, “Introduction to Business Education, ” Nsukka: University press, 2000.

6. U.J. Bell, "Small medium-scale enterprise key failure factors: A comparison between the United Kingdom and Nigeria”, Journal of Social Science, vol. 18, no. 3, pp. 199-207, 2004.

7. S. Bergin-Seers, "Encouraging small enterprise learning: The role of business support agencies", Melbourne Australia: Victoria University, 2000.

8. O.J. Borch, M. Huse, and K. Senneseth, "Resource Configuration, competitive strategies, and corporate entrepreneurship", An empirical examination of small firms. Entrepreneurship Theory and Practice, vol. 24, no. 1, pp. 49-70, 1999.

9. Cagan, "An evaluation of the impact of integrated business and 7 information solution (IBS) in the growth of small and medium-sized enterprises (SMEs) in Nigeria”, Unpublished Master's Thesis. Middlesex University, London, 2009.

10. J.C. Collins, and W.C. Lazier, "Managing the small to mid-sized company: Concepts and Cases". Chicago: Richard D. Irwing, Chapter 5, 1995.

11. R.L. Cross, "Leveraging intellect in a small business: Designing an infrastructure to support today's knowledge worker", Journal of Small Business Strategy, vol. 8, no. 1, pp. 15-34, 2015. http://libjournals.mtsu.edu/index.php/jsbs/article/view/356

12. Down, "Achieving sustainable growth through the adoption of integrated business and information solutions: a case study", 2003.

13. H. Karadag, "Financial management challenges in small and medium-sized enterprises: A strategic management approach", Emerging Markets Journal", vol. 5, no. 1, pp. 26-40, 2015. https://doi.org/10.5195/emaj.2015.67

14. A.G. Shibia, and D.G. Barako, "Determinants of micro and small enterprises growth in Kenya", Journal of Small Business and Enterprise Development, vol. 24, no. 1, pp. 105-118. https://doi.org/10.1108/JSBED-07-2016-0118

15. C. Lechner, and S. Gudmundsson, "Entrepreneurial orientation, firm strategy and small firm performance", International Small Business Journal, vol. 32, pp. 36-60, 2014. https://doi.org/10.1177/0266242612455034

16. O. Lizardo, "The cognitive origins of Bourdieu's habitus", Journal for the Theory of Social Behaviour, vol. 34, pp. 375-401, 2004. https://doi.org/10.1111/j.1468-5914.2004.00255.

17. N.B. Okon, and T.E. Edet, "Small and medium scale business enterprises as a veritable tool for rural development in Nigeria: Challenges and prospects", Journal of Educational Policy and Entrepreneurial Research, vol. 3, no. 3, pp. 87-97, 2016. http://ztjournals.com/index.php/JEPER/article/view/267/247

18. J. Piaget, "Part I: Cognitive development in children: Piaget development and learning", Journal of Research in Science Teaching, vol. 2, pp. 176-186, 1964. https://doi.org/10.1002/tea.3660020306

19. M.E. Porter, "Competitive advantage: Creating and Sustaining Superior Performance”, New York: Free press, 1985.

20. R.S. Schuler, P.J. Dowling, C. Smart, and V.L. Huber, "Human Resource Management in Australia", Australia: Harper educational publishers, 1992.

21. A.G. Shibia, and D.G. Barako, "Determinants of micro and small enterprises growth in Kenya", Journal of Small Business and Enterprise Development, 2017.

22. D.J. Storey, "Understanding the small business enterprises", London: Routledge, 1994. 
23. W. Suryasa, "Historical Religion Dynamics: Phenomenon in Bali Island", Journal of Advanced Research in Dynamical and Control Systems, vol. 11, no. 6, pp. 1679-1685, 2019.

24. E.C. Udechukwu, "Principles and methods of Business and Computer Education", Enugu: Cheston Agency limited, 2003.

25. D.W. Vorhies, and M. Harker, "The capabilities and performance advantages of market-driven firms: An Empirical Investigation”, Australian Journal of Management, vol. 25, no. 2, pp. 145-173, 2000.

26. K. Wilburn, and R. Wilburn, "Demonstrating a commitment to corporate social responsibility not simply shared value", Business and Professional Ethics Journal, vol. 33, no. 1, pp. 1-15. https://doi.org/10.5840/bpej20144216 